\title{
EVALUATING THE PARTICIPATION POLICY IN STRATEGIC PLANNING OF EGYPTIAN VILLAGES エジプト集落の戦略計画における住民参加政策に関する評価
}

\author{
Hatem MAHMOUD* and Takafumi ARIMA** \\ 八テモマへモド，有馬隆文**
}

\begin{abstract}
This study offers a preliminary insight into the participation policy that has been introduced into the decision-making process for strategic urban planning in Egyptian villages. Since 2004, the Egyptian government has made efforts to decentralize urban management by involving local communities in the decision-making process. We analyzed the procedures and practices of the newly adopted participation policy to improve its implementation in the future. Through an analysis of each of the steps of the participatory process, as well as interviews and the questionnaire responses from 50 Egyptian urban planners, the following conclusions can be drawn: 1) Participatory decision making presents an opportunity to solve important urban problems such as unregulated urban sprawl impinging on agricultural lands in Egypt. 2) To ensure that the participation process is fair to all stakeholders, there is a need for the implementation of participatory decision making to be refined. 3) Despite the new policy, the process of involving the community in urban planning can still only be considered to be community consultation, rather than true community participation.
\end{abstract}

Keywords : Decision-making process, Public participation, Egypt 意思決定プロセス，住民参加，エジプト

\section{INTRODUCTION}

\subsection{Background}

Approximately 58\% of the Egyptian population lives in villages ${ }^{1)}$ and rural regions. Egyptian villages are residential agglomerations, which have developed mainly in agricultural regions because agriculture has been the main activity of the population. During the last 20 years, however, these villages have experienced unprecedented growth and urbanization. This has been characterized by the spread of residential areas onto agricultural lands outside the formal urban administrative boundary of each village (as defined in 1985). The growth rate of villages ranged from $40 \%$ to $700 \%$ of the area within its former urban boundary ${ }^{1)}$. This informal urban growth has led to many problems. For instance, agricultural land area has decreased by approximately 1.5 million acres $\left(6300\right.$ million $\left.\mathrm{m}^{2}\right)$. This equates to a reduction of approximately $36 \%$ of national agricultural land ${ }^{2}$. In addition, this informal growth has led to insufficiencies in national infrastructure (such as worn-out roads) and poor living conditions. Although many of the policies were introduced by the government to address the problems arising from the increasing urbanization of villages, these policies have failed to achieve real progress toward resolving these issues. This is primarily because the policies implemented did not reflect local conditions or the communities' needs ${ }^{3}$.

The General Organization of Physical Planning (GOPP) is a governmental authority following the ministry of Housing, Utilities and Urban Development. GOPP is responsible for policy-making for planning and sustainable urban development in Egypt. GOPP has introduced a comprehensive strategy to address the urban problems. This strategy is divided into six points as follows: 1) Re-planning and developing the current city and villages urban, 2) the proper management and exploitation of natural resources, 3) develop new hubs for the Egyptian urban, 4) resettlement the growth of population to stop the growth of the slum areas, 5) the sustainable of development projects, 6) identify the priority projects that are accepted and approved by the local communities. To achieve this strategy, GOPP introduced several policies and initiatives, among them introducing an initiative aiming at decentralizing the decision-making process. This initiative is based on the principle that the public should participate in urban planning. This initiative was adopted for the first time in a national governmental project "Preparing Strategic Plans of Egyptian Villages (PSPEV)" (strategic plans identify the need for future urban expansion, development priorities, and sources of funding). The objective of this project was to develop a national strategy for improving the urban situation in Egypt. The principle of participatory management has been introduced in cooperation with the United Nations Program for Urban Settlements in Egypt (UN-Habitat) in 2005. The methodology used to prepare these plans was the same as that used by UN-Habitat to prepare strategic development plans in several cities in Somalia" ${ }^{4)}$.

\subsection{Objectives}

The concept of public participation in community decision making has been in use in Egypt since the 1960s through local administrative systems. This

* Doctor Candidate, Graduate School of Human-Environment Studies, Kyushu Univ.

** Assoc. Prof., Faculty of Human-Environment Studies, Kyushu Univ., Dr. Eng.
九州大学大学院人間環境学府 博士課程

九州大学大学院人間環境学研究院 准教授·博士 (工学) 
paper discusses the new policy of participation in the decision-making process in preparing national planning strategies in Egypt. In addition, this paper discusses the current situation with regard to the positive and negative aspects of the newly adopted participation policy based on a survey of Egyptian urban planning professionals.

The objective of this study is to evaluate the newly introduced process of participation in strategic planning in Egyptian villages. We aimed to understand the context within which participation is taking place. It analyzes the current participatory strategy in Egypt and assess whether it incorporates true community participation. The final objective of this study is to propose modifications to the participatory management approach which will enhance the implementation of the policy in the future.

Arnstein's ladder of participation ${ }^{[1]}$ was used quantify the degree to which the community participated in strategic planning procedures, and a survey of qualified Egyptian urban planners was used to assess the quality of the implemented procedures.

\subsection{Related Studies}

Globally, there is a trend to increase community participation in decision making, especially in the creation of urban development policies, although many countries have adopted community-based decision-making principles into a wide variety of fields. Despite the global acceptance of community-based decision making, the strategies adopted to implement it vary from one society to another. This is due to cultural, economic and political differences between countries. Thus studies address public participation as either a general concept or in a specific community as a case study.

The Egyptian government has a short history of participation in urban planning. Before 2004, public participation in urban planning had not been widely implemented. It was limited to small projects initiated in cooperation with international organizations. Thus we can divide literature on Egyptian communitybased decision making into two groups. The first group contains all studies conducted prior to 2004. These studies address the urban planning law and the importance of implementing policy changes to involve citizens in the decision-making process. Esam M. Aly ${ }^{5}$ argued for decentralization of decision-making power. He found that there was an urgent need for better resources for local administrative units to support their facilitation of public participation.

The second group contains limited studies conducted after 2004. These studies is focus on analyzing the newly introduced policies. All these are case studies based on the personal experience of urban planners who have been responsible for implementing the new polices. Mostafa Madbouly ${ }^{1)}$ supported the new methodology of participation in preparing strategic plans. He made several recommendations to improve the success rate of community participation in strategic planning. One of the recommendations that he made was to make sure that the agreed plans were implemented. This strengthens the confidence of the citizens in their government.

Our study analyzes the newly adopted community participation process in Egypt more deeply than previous studies, and also evaluates its practicality by means of a questionnaire to which 50 Egyptian urban planners responded. In addition, interviews of urban planning professionals who have been involved in the community participation process were conducted. This paper culminates in recommendations for improving participatory urban planning in the future based on an analysis of these questionnaires and interviews.

\subsection{Methodology}

The study is based on a theoretical analysis of a field survey. This survey was conducted from November 2009 through to February 2010 in Egypt. During this period, the researchers endeavored to understand the participation process, obstacles to the process, and the potential for participatory urban planning. Documents relevant to this objective were collected. The methods used in this study can be divided into three main parts:

1. Review of the regulations relating to participation in urban planning in Egyptian law: This was conducted through a review of available governmental documents relating to urban planning laws and community participation in decision making in Egypt, and fieldwork involving questionnaires and interviews with urban planners.

2. Preparing Strategic Plans of Egyptian Villages (PSPEV): This step was conducted over 2 months, in which we collected information about the PSPEV project and the participation activities within it. This was done through interviewing academic planners who were involved in participatory planning work, and through interviewing GOPP officers. The same procedures for implementing participatory urban planning were used in all villages involved with the PSPEV project. Of these villages, Elbarsha village was selected as a case study because it was recommended by urban planning professionals as a typical example of the newly adopted participation process. This study deals with the policy of participatory urban planning and endeavors to find means to enhance the process of participation, and thus its focus is general. A village case study has been introduced to illustrate the participation procedures and outcomes. Three visits were made to the case study village of Elbarsha, and the head of the village planning team was interviews three times. Documents relating to the village strategic plan were also collected.

3. Evaluation of the participation process: This step was divided into two parts. The first was quantifying the level of participation using Arnstein's ladder of citizen participation. This is a widely-known tool for rating the level of community participation in a decision-making process. Arnstein's 'ladder' has eight 'rungs', which correspond to eight degrees of participation. The second part of evaluating the participation process was a survey conducted by distributing 90 questionnaires to academic planners and GOPP officers. There were 52 respondents to this questionnaire, and two of these were excluded from the analysis because they were incomplete. The questionnaires were used to identify the most significant difficulties and shortcomings in implementing participatory strategic planning. 


\section{REVIEW FOR REGULATIONS RELATED TO PARTICIPATION IN URBAN PLANNING IN EGYPTIAN LAW}

Public participation terminology has been in use in Egypt since the 1960s in the political and administration fields. In the field of urban planning, however, the last 50 years have not witnessed effective public participation in decision-making.

\subsection{Urban Planning Law}

The first urban planning law was issued in 1982 (no. 3, 1982). This law made the GOPP the authority responsible for making policy relating to planning and urban development ${ }^{6}$. This urban planning law contains a very brief reference to participatory urban planning. Public participation is mentioned in this law only once, when it outlines the steps required for preparing general plans ${ }^{[2]}$. It states that the LGU (local government unit) ${ }^{[3]}$ is required to display a draft of proposed plans at its headquarters, where citizens who so wish can view and comment on it. Following this, the final decision on the plan is made based on the collected opinions of the citizens and the opinion of the GOPP. It also requires the project to be shown to the local council (which is elected by the citizens). Finally, it is submitted to the planning minister, who either certifies it or returns it with notes on how it should be modified.

According to this law, urban plans should be developed locally and then approved centrally. However, the administration system responsible for this suffers from many problems. Additionally, LGUs suffer from several weaknesses, including a lack of staff qualified to carry out these responsibilities ${ }^{7}$. As a result, this form of public participation can be considered simply a means of evading responsibility for decisions and a token gesture at community involvement. Furthermore, this law has no mention of citizens' involvement in the decision-making process. Finally, the role of the GOPP was advisory only.

\subsection{The Unified Construction Law (Present Situation)}

The year 2004 witnessed the implementation of decentralizing urban planning processes within the GOPP. This was initiated through the establishment of seven regional centers whose role is to support the local government in their urban planning responsibilities ${ }^{7}$. To enhance participation in urban decision making, in 2005, the GOPP introduced an initiative that involved the citizens in the PSPEV project. The project's reference book mentions the importance of facilitating effective community-based tools to achieve community-based strategic urban planning, and to expand the community's participation in setting goals and priorities. For this project, the GOPP assigned responsibility for involving the community to the planners. These people were recruited from universities specifically to conduct this process. In 2008 the Unified Construction Law $($ no.19, 2008) was issued. This law stressed adherence to the procedures laid out in the aforementioned reference book ${ }^{8}$.

To understand the situation fully, the following four points should also be taken into account. 1) Participation throughout the decision-making process is a new process in Egypt. 2) Egyptian citizens are accustomed to centralized decision making, where they have right to participate in the decision making process. 3) The participation process is now subject to the Unified Construction Law (no.19, 2008). This law forces the planners to follow the participation guidelines listed in the PSPEV reference book throughout the process of preparing the strategic plans.

\section{PREPARING STRATEGIC PLANS OF EGYPTIAN VILLAGE PROJECT (PSPEV)}

\subsection{Situation in Egyptian Villages}

Most Egyptian villages share many of the same characteristics and features. They are characterized by general properties such as: (1) being located in agricultural lands, and (2) being situated along the Nile River or water canals. Villages consist mainly of three elements. These are: 1) houses (including barns for poultry and livestock), 2) a multipurpose square used as a market and for social events, and 3) cemeteries, based on the social custom of burying the dead in graves near urban clusters ${ }^{2}$. The urban structure in most villages begins with a semicircular residential mass surrounded by an outer ring-road. The width of this road does not exceed 6 meters, and it in turn is connected with an internal curved cul-de-sac. Because of the informal development of the residential mass, however, urban sprawl develops outside of the ring-road. Villages now extend well beyond the original village area, which forms a small central core of the new village (Fig. 1) $)^{9}$. On average, residences take up approximately $85 \%$, and services occupy $9 \%$ of the land areas of an urban cluster. Services include all village activities except those relating to residence (education, health, shops, etc.). The remaining $6 \%$ of village area is taken up by roads ${ }^{2}$. Villages were divided into six categories based on their population. Category one (1) includes very small villages (less than 2,000 people). Only $14 \%$ of villages were classed as category one. Category two (2) includes small villages of between 2,000 and 4,999 people. This category includes $36 \%$ of all villages. Category three (3) includes moderatesized villages, with populations between 5,000 and 7,999 people. This included $23 \%$ of all villages. Category four (4) includes those villages which are slightly above the average, with populations between 8,000 and 16,999 people. This includes $23 \%$ of villages. Category five (5) villages are large villages, with populations between 17,000 and 24,999 people. Only $3 \%$ of

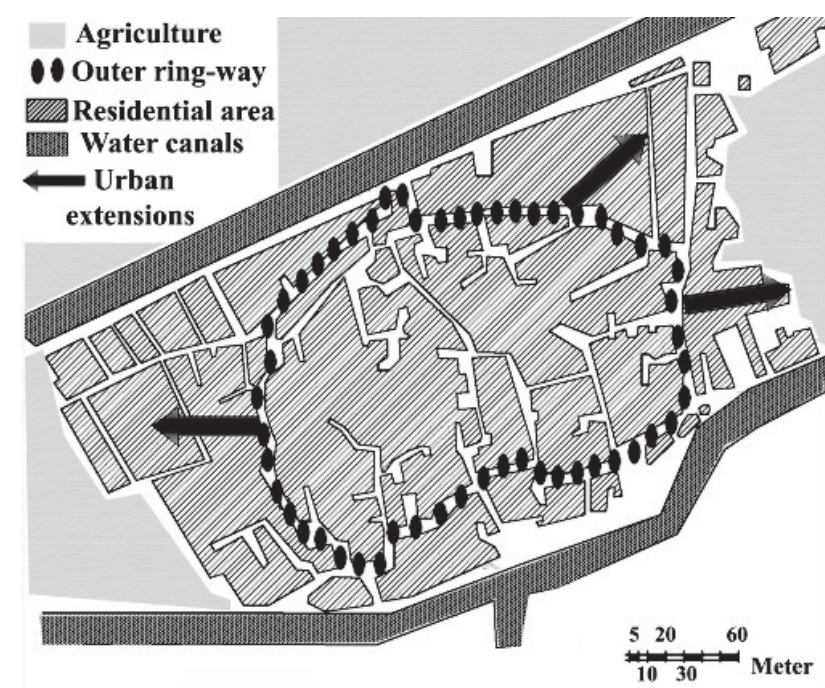

Fig.1 The ring road in the urban structure of villages in Egypt 
villages fit into this category. Category six (6) villages are the largest. They have populations over 25,000 , and comprise only $1 \%$ of villages $)^{9)}$.

Most Egyptian villages have not been formally planned, but instead left to extend randomly over agricultural lands surrounding the village. Thus most Egyptian villages suffer from physical, social, and economic problems relating to their inefficient urban structure. This has led to a decline in the village economy and living conditions ${ }^{9}$. As a result, there is a high rate of illiteracy among the population in rural areas, with $42.7 \%$ of those aged above 15 years remaining illiterate, and in 2004, 27.4\% of the rural population were living in poverty ${ }^{7}$.

\subsection{Decision Making and Participation Activities in the PSPEV Project}

The PSPEV project is a governmental national project that aims to create strategic urban development plans using a newly developed methodology. This methodology is based on involving citizens in each participating village (4,623 villages were included in the project) in the decision-making processes relating to these plans. The main aims of this project were to assess village needs, define the new village urban (administrative) boundary, and clarify the vision of village development in the future in respect to the social, economic and environmental goals of the communities.

In the past the decision making process was conducting between GOPP members and the planners' team only, in (Fig. 2) The stakeholders who were involved in the new decision-making process in PSPEV are presented ${ }^{10}$. The stakeholders were divided into two groups 1) The decision makers comprising two groups: a) GOPP members as the central government representative, b) the planning team (was selected by the GOPP) comprising academic planners, infrastructure consultants, social and economic consultants, and assistants. The planning team task was to prepare the strategic plan documents and reports, arrange and manage the meetings, analyze the proposals, and suggest solutions. 2) The Development Partners comprising three groups who were involved in the decision-making process from the local communities: a) local government-local administration, directorates, sector committees (Health, Education, and Transportation), and the departments responsible for infrastructure and social funds, b) employment-economic institutions, private companies, and educational institutions, and c) non-governmental partners-citizens, non-formal groups such as local community leaders and famous families who own wide areas of lands within the village, and Non-Profit Organizations (NPO's).

The duties of the development partners are as follows $\left.{ }^{10)}: 1\right)$ the local administrative body is responsible for making information available, and for defining the other development partners; 2) the other development partners participate in the decisionmaking through interviews, meetings and workshops; and 3) development partners participate in defining development activities and prioritizing projects. Furthermore, they can suggest alterations to the roles of partners, changes to financing, and modifications to the implementation of development activities.

For the first time in Egypt, the local communities play a vital role in decision making in urban planning projects. This framework adds a new responsibility for the planner: managing effective communication with the development partners. This study evaluates the execution of this new responsibility, however, before evaluating the participation process it is necessary to first define its steps.

3.3 The Participation Process Steps in the PSPEV Project (Elbarsha Village as an example)

The PSPEV reference book included a framework for preparing strategic plans (Fig. 3). From the project's references book and our interviews with the project coordinator in Asyut and Minya prefectures (a professor at Assuit University ${ }^{[4]}$ ) and with the main planner of Elbarsha village ${ }^{[5]}$, that participation in the decision-making process will be described. Elbarsha Village is taken as an example to demonstrate the steps the participatory planning process.

Elbarsha village is under the directorship of the Deer Elbarsha local unit, which in turn is accountable to Mallawy province, Minya prefecture. The preparation of the strategic plans is divided into four stages. These are:

A) The first stage: Preparation and public input (2 weeks): Work started

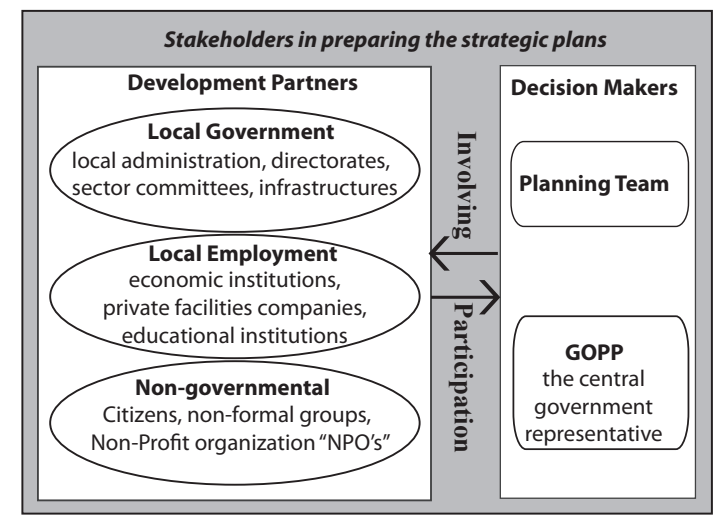

Fig. 2 Stakeholders in PSPEV project

Table 1 The local unit of Deer Elbarsha statistics ${ }^{11)}$

\begin{tabular}{|l|c|c|c|c|}
\hline Village Name & $\begin{array}{c}\text { Population } \\
1985\end{array}$ & $\begin{array}{c}\text { Area } \\
1985 \text { "Acres" }\end{array}$ & $\begin{array}{c}\text { Population } \\
2005\end{array}$ & $\begin{array}{c}\text { Urban Cluster } \\
2005 \text { "Acres" }\end{array}$ \\
\hline Elbarsha & 16289 & 67 & 25901 & 148.89 \\
\hline
\end{tabular}

Table 2 The expected future statistics of Deer Elbarsha local unit ${ }^{11}$

\begin{tabular}{|l|c|c|c|l|}
\hline Village Name & $\begin{array}{c}\text { Population } \\
2022\end{array}$ & $\begin{array}{c}\text { Boundary area } \\
\text { 2022 Acres }\end{array}$ & $\begin{array}{c}2005-2022 \\
\text { Population }\end{array}$ & $\begin{array}{c}2022 \\
\text { Urban sprawl }\end{array}$ \\
\hline Elbarsha & 37426 & 169.5 & $\% 44.50$ & $\% 13.84$ \\
\hline
\end{tabular}

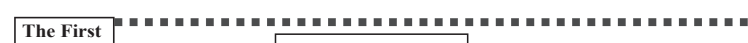

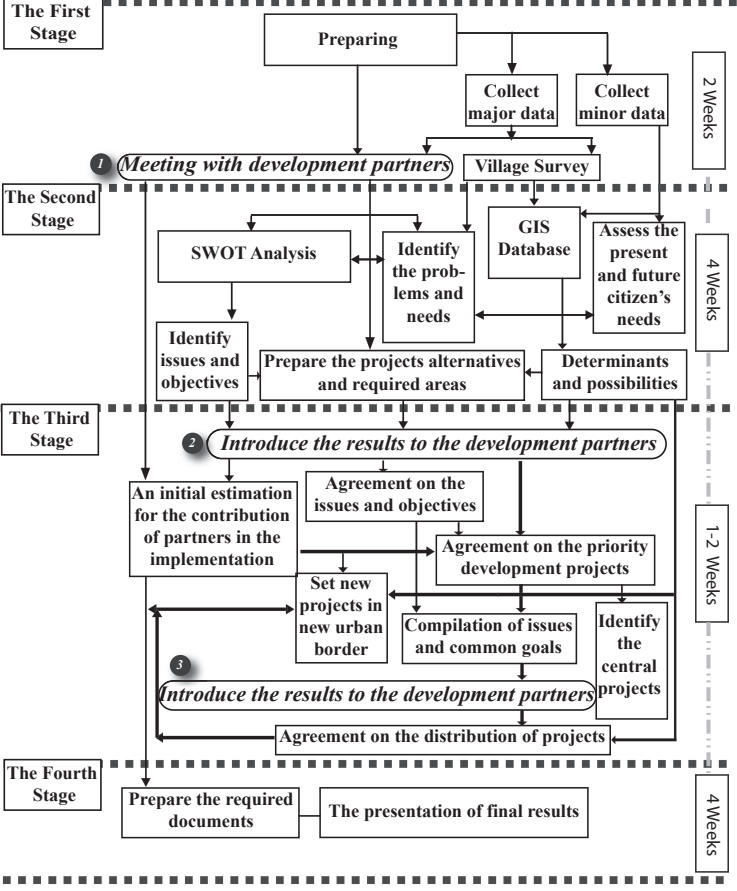

Fig. 3 The framework of PSPEV project ${ }^{10}$ (italic font for the participation activities) 
with collecting data about the villages. This included statistics about the development of the village (minor data) (Table 1) as well as surveying the village, collecting maps and new aerial views, and identifying the key variables that were likely to have an effect on the strategic plan (such as identifying which areas are not in use) (major data). Through cooperation with the LGU staff in Elbarsha village, the development partners were identified and letters were sent to them inviting them to participate. Additionally, general announcements were posted throughout the village inviting citizens to attend to the meetings.

The project's success depended on a rapid assessment of citizen's needs and expectations, thus the initial stage ended with the first meeting of development partners. However, only 11 development partners attended this meeting. It commenced with a public hearing about the village situation and then discussions were opened about the options available to the village. A questionnaire and recent aerial photographs were distributed. The aims of the meeting were to: 1) review the village's aerial view with respect to the village boundaries, streets names, and the main village features; 2) reach a consensus on what the most important issues facing the village are, what alternatives are available to avoid these problems, and what would be required to solve them; and 3) define the roles of all partners in the urban development planning process.

B) The second stage: Design (4 weeks): In this stage, the data collected in the first stage were analyzed to determine the expected growth and the necessary services for each village by the target year of 2022 (Table 2). The present and future citizen's needs were assessed. The villages' survey is uploaded to the Geographic Information System (GIS) database. Based on the studies that planners prepared for village, a SWOT (Strengths, weaknesses, opportunities and threats) analysis was prepared for each of the social, economical, environmental, infrastructure, and urban development areas of study.

The analysis of the village showed that it was experiencing the same problems as most other Egyptian villages. These include informal urban sprawl onto agricultural lands because of the absence of strategic planning and lack of updates to the urban boundary since 1985. This has resulted in an absence of clear limits to urban extension (Fig. 5). Other common problems include solid waste management, a lack of health and education services, and deficiencies in the infrastructure (such as unpaved or unilluminated roads (Figs. 6, 7).

The team of planners then prepared development policies directed at stopping the urban encroachment on agricultural lands, as well as formulating solutions to the other local issues which have been identified. These solutions were presented as a list of alternatives and possibilities, such as construction of an elementary school, primary school, high school, kids library, ambulance unit, fire unit, social unit, communication center, hospital, and girl's training center ${ }^{11)}$, the land required for these projects, and a plan to accommodate population growth.

C) The third stage: public choices and decisions (1-2 weeks): The second meeting was held in the presence of LGU officials, state property officials, members of the local council, a representative of the GOPP, senior representatives of the village such as the mayor, citizens, and the planning team. Only 16 development partners attended this meeting. The meeting started with a presentation of the proposed development policy and the alternative projects, and then discussions were opened regarding the participants' responses to the planners' ideas. The meeting's aim was to: 1) reach agreement on which proposed alternatives should be adopted and how they should be funded, and identify the directions of urban growth; 2) identify which activities prioritized by the citizens were congruent with the long-term strategic development plan; and 3) prepare an initial estimation for how much of a financial contribution each of the development partners would need to make.

At the end of the meeting, questionnaires were distributed to the participants. This questionnaire included aerial views, maps, land use maps, and building height and status maps. The whole meeting was recorded on video. The final strategic plan was formulated based on the results of these questionnaires, and was introduced at the third meeting.

The third meeting began with a presentation on the data that had already been collected about the village. This included information on the village's urban growth and development since 1985, available services and clarification of any deficiencies in these services, the current infrastructure status, population development and expected growth, and the expected growth of the urban boundary. Finally, the planning team introduced the proposed strategic plan. Again, only 16 development partners attended this meeting. Based on open discussion, this meeting's aim was to make decisions regarding the distribution of resources to projects, and to define the new urban boundary.

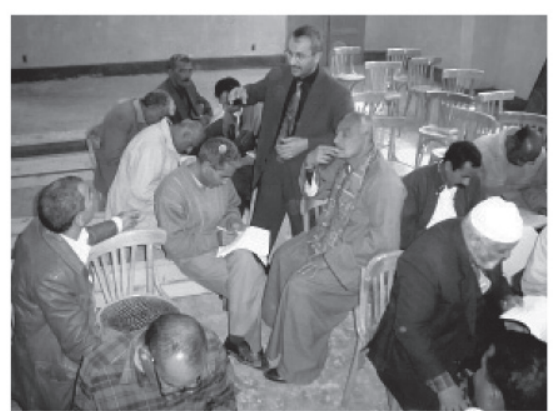

Fig. 4 A workshop in Elbarsha village, Minya estate, Egypt

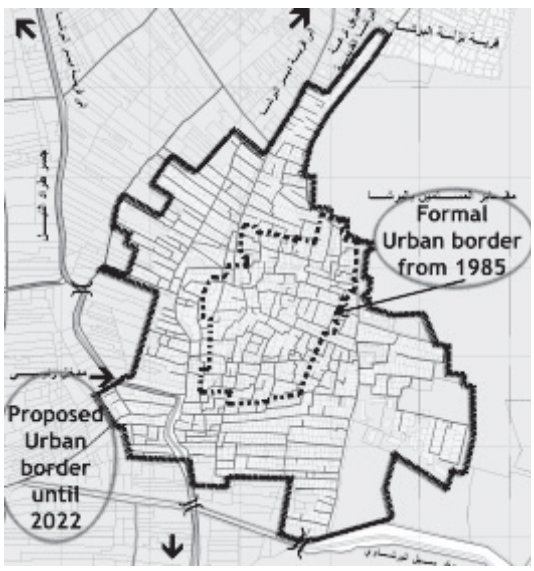

Fig. 5 The urban development of Elbarsha Village $^{10)}$

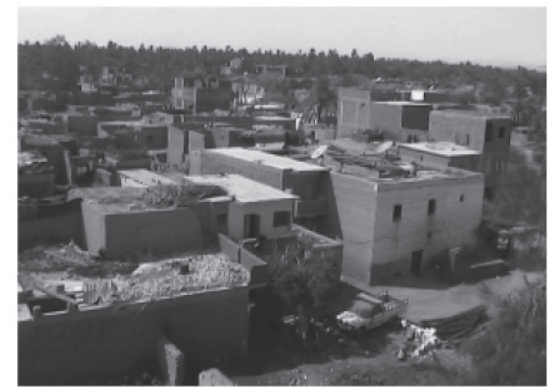

Fig. 6 The present situation of Elbarsha Village

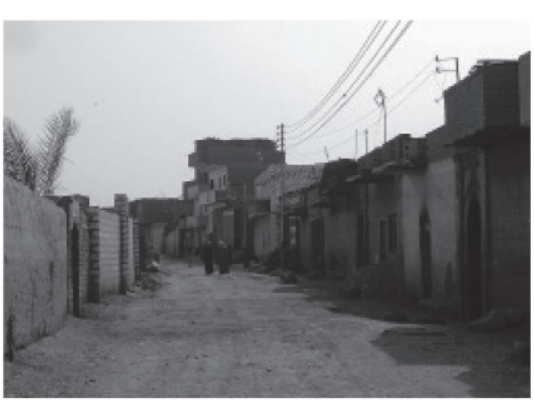

Fig. 7 internal roads in the villages of Elbarsha 
Based on this meeting, the priorities of urban development in the village were ordered as follows ${ }^{11)}$ : 1) to use available land and the agricultural pockets to accommodate population growth up until 2022;2) to increase the efficiency of existing educational and health services; 3 ) to build a high school and an elementary school; and 4) to build an ambulance unit, and a fire unit.

D) The fourth stage: Documentation (4 weeks): In light of the outcome of this meeting, and after all involved in developing the strategic plan have reached agreement on the proposed projects and the urban border, the decisions were finalized. New maps detailing the new urban boundary, and documents detailing the other aspects of the development plan were prepared (Fig. 8). The planning team was required to submit documents certifying that the development partners had agreed on the new urban border of village, the relative priority of proposed projects, donations, and contributions. These documents required the signatures of the development partners, the head of the LGU, and the regional coordinator. In addition pictures and video records of the meetings with development partners were required to be submitted.

\subsection{The Strategic Plan Output for Elbarsha Village}

The major points of this report were: prioritizing activities (projects) for the village community, identifying the new urban (administration) boundary for the village, introducing the legal and structural requirements for development to the community, identifying the land uses of settlement areas and extensions, and finally, describing the proposed projects, their initial costs, and what each organization involved would be required to contribute.

Despite the GOPP's adoption of the strategic plan in 2008, to date (2010), none of the agreed projects have been carried out.

\section{THE EVALUATION OF THE PARTICIPATION PROCESS}

This evaluation is divided into two parts. The first part is the evaluation of the participation procedure using Arnstein's ladder of citizen participation. The second is an evaluation of the practice and results of the participatory planning process using a survey.

\subsection{Why Arnstein's typology}

In 1969, Sherry Arnstein formulated a means of classifying citizen participation in planning. This classification system is known as Arnstein's ladder of participation. This typology was used despite being a western theory, because Egypt, like many countries in Africa, has a long history of European colonization (from 1100s until 1952). The effects of European colonization in Egypt are reflected in many aspects of life, such as the architecture, the infrastructure, the transportation network, the urban planning, Culture, and lifestyle. The long history of Western colonization and especially the contribution in infrastructure setup and land use planning has a profound influence of western planning theories in Egypt. By this, it will be agreed that it is possible for western developed theories such as the Arnstein Ladder of Participation to be applicable in Egypt.

Moreover, Most of the developing countries have not been able to develop their own theories; instead, these countries receive or adopt theories from the developed (western) countries. What is important, and as it was described in this study that Egypt has a short history with the participation in urban planning, for that we had to localize the Western theories to meet the local condition in Egypt. In addition to this, Arnstein in her study "The Ladder of Citizen Participation" didn’t strictly limit her typology to be used in the western communities only; this extends opportunity for other non-western communities to apply the theory in other similar case such as it was applied in this study.

\subsection{Analysis of Procedure Steps}

The degrees of participation in Arnstein's ladder of citizen participation are divided in eight categories or 'rungs' of the ladder. The lowest rungs are manipulation and therapy. These two rungs describe levels of "non-participation". They involve the decision makers educating and informing citizens, rather than involving them in the decision-making process. Rungs 3 and 4 involve informing and consulting with the public, and can be considered "token" levels of participation, because citizens are informed about the decision-making process and have a voice, but they are without power to ensure their views are considered. Rung 5 is placation. This is considered to be a higher level of tokenism; however, the right to make decisions remains with the authorities. Rungs 6 "partnership", 7 "delegated power", and 8 "citizen control" are the top levels of participation in Arnstein's ladder ${ }^{12)}$.

In the Egyptian case, the goal of the GOPP was to achieve not only consultation, where the public is asked to decide between options ${ }^{13)}$, but full public participation. However, in this case, the planners prepared a SWOT analysis and presented a range of potential outcomes in accordance with the public's needs and priorities. For example, the planners propose a new urban boundary for a village and perform a SWOT analysis. The

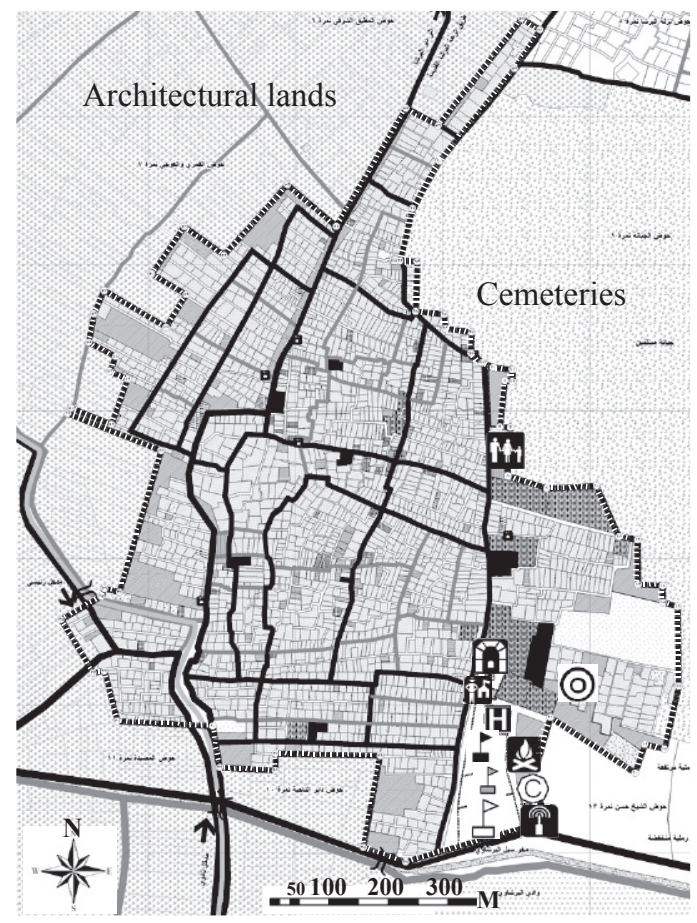

Fig. 8 Proposed services and roads network in the strategic plan of Elbarsha village ${ }^{10)}$ (edited by the first author)

Hospital
Fire Unit
Social Unit
Main Road


participants then understand the constraints and other details involved and come to a decision on what they think is the best course of action. Once they have presented their views, the planners prepare a range of options in accordance with these views, and then the development partners vote on these options.

In (fig. 9) the steps of the participation process are presented, and types of public involvement at each point are listed beside the arm ( This demonstrates that public involvement in strategic planning takes place in three stages. First the public are provided with information and then their comments (public input) are sought. After that, planners prepare a range of options, the plans are again presented to the public and the participants choose which options they want implemented. The third step is where the public's choices are returned to the planning team, where a final decision is made on what actions will be taken.

This process is intended to lead to effective public participation. In the Egyptian case, however, the steps detailed in the PSPEV reference book do not give the public the power to monitor the implementation of plans. Consequently, because there is no law, nor even guidelines in the project reference book, that would make the government accountable for implementing what has been agreed upon in discussion with the citizens, there is no assurance for the citizens that their participation will have results.

\subsection{Observations Encountered in the Procedural Analysis}

In the Egyptian case, procedures have been changed to increase public participation in planning; however, although citizens have the power to participate throughout the decision-making process, they remain powerless to monitor the implementation of these decisions or to hold the government accountable for their implementation. Thus citizens can hear and be heard throughout the decision-making process, but have no power to ensure that agreed courses of actions are followed through. Thus participation without redistribution of power is an empty ritual. The level of participation in this undertaking can therefore be classified as "Consultation" in accordance with the fourth of the eight rungs in Arnstein's ladder of participation. To achieve true participatory planning, a means of empowering the citizens to monitor and enforce the agreed outcomes of the participatory decision-making process needs to be implemented.

\subsection{Analysis of the Steps: Survey Results and Observations}

The practical evaluation of the participatory planning approach is based on a questionnaire, in addition to individual interviews and a number of anecdotes used to describe and illustrate the various aspects of the participation process. As well as interviews with GOPP officials, fifteen interviews were conducted with academic planners who had participated in the PSPEV project and together prepared strategic plans for 140 villages.

The participants in the questionnaire were asked at which planning stage they would prefer citizens to be involved in the decision making (multiple answers were permitted). Sixty-four percent $(64 \%)$ of respondents favored the status quo, were citizens' priorities the options presented by the planners, $60 \%$ of respondents also felt citizens should be able to participate in the formulation of options, however only $18 \%$ of the respondents were in favor of involving citizens in the final decision-making stage (Fig. 10).

Many of the planners believe that because participatory planning is still a new process in Egypt, it should be introduced gradually, especially in a project such as PSPEV. Planners also felt that the high illiteracy rate of citizens (in some villages up to 63\%) was an impediment to effective participation. They felt it was more effective to collect the public's opinions in the early stages, but to leave the final decision in the hands of informed and experienced professionals.

When asked what difficulties there had been in collecting data from citizens regarding the present situation in their village, $74 \%$ of respondents stated that a significant problem was that citizens were unaccustomed to participating, and $72 \%$ stated that citizens did not believe that their opinions would have an impact on the decision (Fig. 11). This led to a low number of attendees at most meetings. Surprisingly, however, time and project budget were not often nominated as significant problems (only 18\% - 20\% of respondents reported it as an issue). All respondents reported favorably on the level of cooperation of the citizens. .

Citizens' lack of familiarity with participating in decision making can be traced back to historical and political factors. Egypt was converted from a kingdom to a republic in 1956, and soon after was involved in two wars (in 1967 and 1973). The idea of a modern government as a servant of the people is thus a relatively new concept. Positive experiences are needed to change the cultural perception of government as something that is alien, to being a cooperative

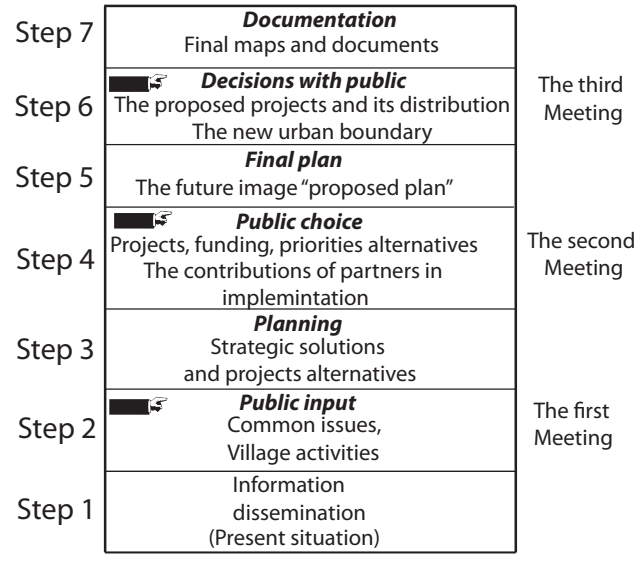

Fig. 9 Participation activities through the decision making

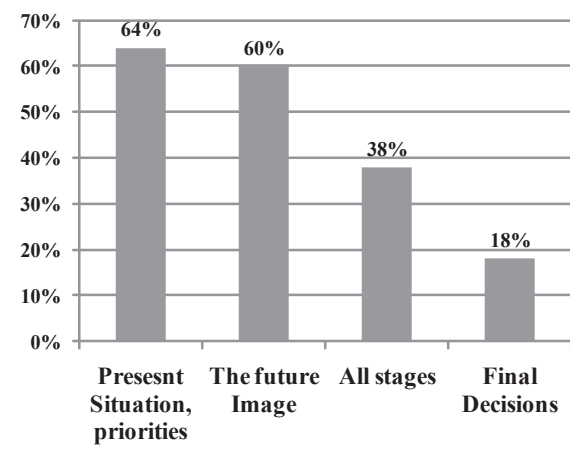

Fig.10 Involving local communities' stages

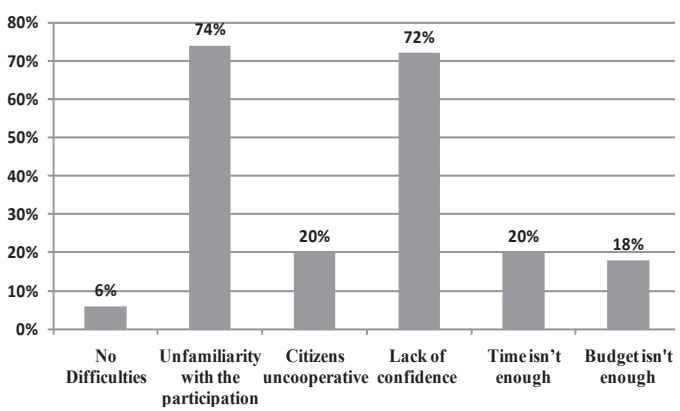

Fig.11 Difficulties faced planners to collect opinions 
and supportive advocate of citizens' needs and desires. Centralization of the decision-making process and the lack of strong competition in government are important political reasons for the lack of participation. This is demonstrated by the percentage of the population that voted in the 2000 election, only $24.1 \%$ of the eligible registered population ${ }^{14)}$.

Planners allowed multiple methods for the community to present their ideas about the present situation. Seventy-eight percent (78\%) elected to explain orally, 68\% used maps and sketches, and $54 \%$ physically toured the sites (Fig. 12). There are no obligations from the GOPP to use specific methods, but planners tried to use simple methods appropriate to the culture and educational level of citizens. There were, however, notable difficulties communicating ideas, which indicate that appropriate tools should be developed for future use.

With regard to the methods of communication employed by the planners to deliver the future image of village, $46 \%$ stated that they prefer to use a combination of three methods, $42 \%$ preferred only two tools, and only $12 \%$ relied on a single method of communicating their ideas to the development partners. Most planners chose oral explanations as their preferred method (68\%); however, 62\% also reported using maps and sketches (Fig. 13). The same methods were preferred for both collecting opinions on the present situation and for expressing ideas for the future. Most planners did not favor using advanced tools such as three dimensional computer graphics or animation (only $36 \%$ - 40\% reported preferring these). In general, however, most faced difficulties in communicating their ideas to the citizens. Eighty-two percent reported that they believed the citizens could not visualize the proposed idea easily, $38 \%$ reported that the time allocated in the project framework was not sufficient (Fig. 14). Most significantly, however, $90 \%$ of planners felt that using more advanced visualization tools would enhance the participation process (50\% reported that they strongly agreed, $40 \%$ simply agreed) (Fig. 15).

It was observed that most planners did not choose to use advanced tools in the participation process. This was because using advanced tools requires more time and a larger budget that was available for the project. However, because citizens' educational level significantly affects their ability to visualize the planners' proposal, the planners have a responsibility to develop and use visualization tools that will help overcome this difficulty.

When asked whether the planning policy was sufficient to generate decisions that reflect the citizens' needs, $40 \%$ of planners disagreed, and 32\% selected 'neutral' (Fig 16). This high percentage of dissatisfaction is due to the lack of clarity on what the results of the new policy have been. Involving citizens in the decision-making process requires a long time before clear positive outcomes can be demonstrated; however, once they are, they can be expected to give both citizens and planners a sense of satisfaction.

Regarding general problems with public participation in planning and decision making in Egypt, $82 \%$ of planners felt that citizens' lack of interest was a problem, $64 \%$ felt there were deficiencies in the policy, and $48 \%$ felt that the project suffered from economical problems (Fig. 17) (multiple selections were permitted). A lack of familiarity with participation is a normal result of centralized urban policies. Additionally, economic problems are not surprising given the high rate of poverty in Egypt $20.2 \%$ (and as high as $61 \% 16$ in Asyut prefecture).

The questionnaire also contained a section where respondents were free to write their own comments. In this section $82 \%$ mentioned that there was a lack of diversity among the citizens who participated in the meetings (youth, women and the disabled were not well represented). Another frequently reported problem was that many of the participants prioritized their own personal interest over the public good. For example, participants who were land owners frequently requested that the village growth be toward their land.

A lack of diversity among development partners was a significant problem. For example, as a result of Egypt's social customs, women did not participate in any meetings. A lack of participation in decision making by women is a significant problem faced by Egypt as a whole. Although (according to census data) $48.9 \%$ of Egyptians are female, only $1.7 \%$, of seats in

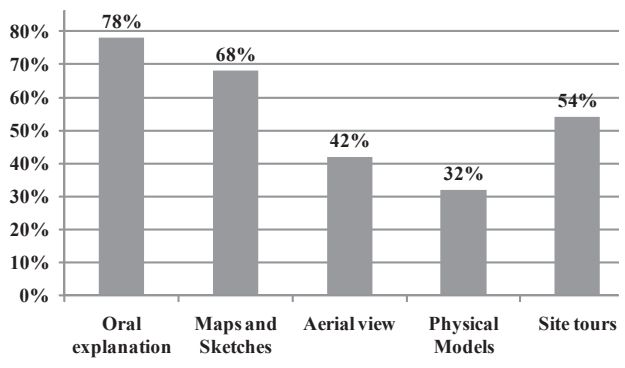

Fig.12 Methods used to collect present situations

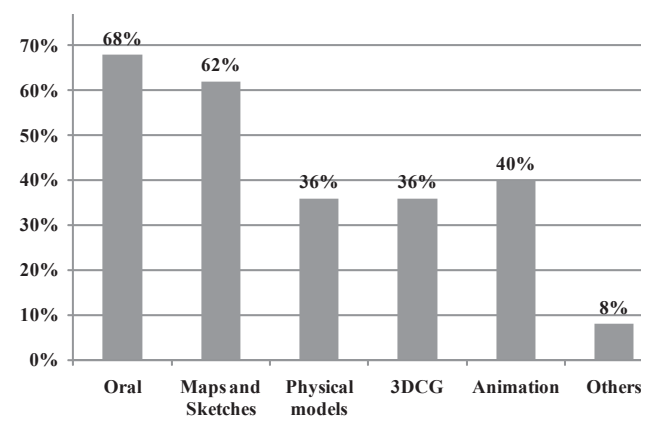

Fig.13 Preferred tools in delivering the future image

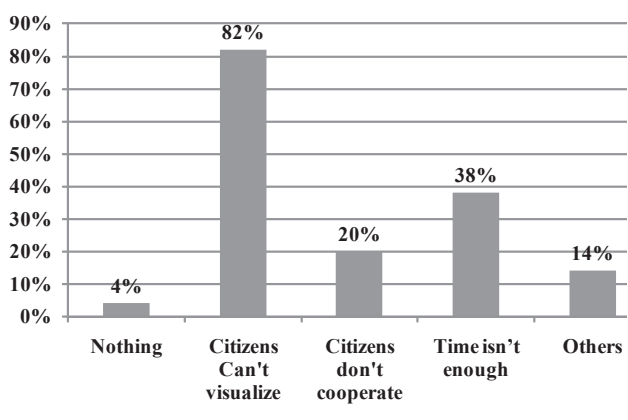

Fig.14 Difficulties face planners in delivering their ideas

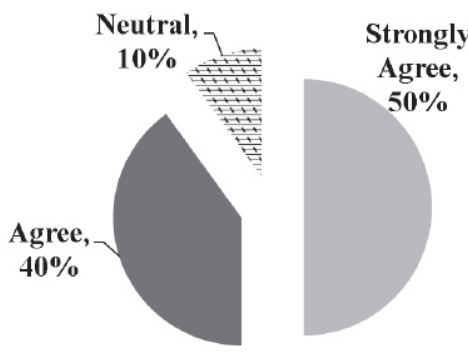

Fig15 Using more advanced tools

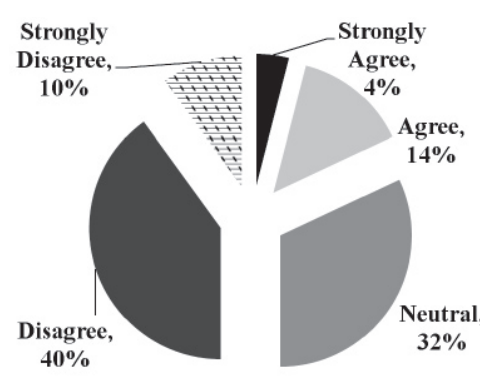

Fig. 16 Adequacy of planning policy to reflect the citizen's needs 
Local Popular Councils are held by women, and $2 \%$ of seats in the People's Assembly ${ }^{15}$. To overcome this inequality in participatory urban planning special procedures will be required, such as arranging parallel interviews that are organized and administered by female members of the planning team.

\subsection{Proposed Approach to Enhance the Future Practices}

Although the newly adopted process of participation has achieved an appropriate shift towards decentralizing the decision-making process by identifying the citizen's needs and priorities, (as it introduces an important opportunity to solve urgent problems such as urban sprawl over agricultural land) the practice still suffers from some shortcoming. (Fig. 18) concluded the main positive and negative aspects related the participation process, drawing recommendations for the negative ones. Hence, the following issues should be addressed in the future: 1) Strengthening decentralization policies to encourage citizens' interest in participating, and to rebuild their trust in the government. This will help to overcome the political and historical factors that affect the quality of citizens' participation; 2) committing to overcoming the needs that are identified during the citizens' participation by introducing a schedule for the implementation of proposals agreed to in discussion. This should be done quickly to convince citizens of the value of participation. Additionally, it is important to introduce a monitoring and accounting policy; 3) Introducing special procedures to address the social customs of villages to facilitate more diversity at meetings. For example, it should be a requirement that there is a minimum number of attendees from minority and special needs groups (e.g. Young or disabled people) for the meeting to be classed as legal, and parallel meetings should be conducted for women; and 4) Introducing physical and moral incentives to encourage citizens to participate in meetings, and develop more effective methods of communication between decision makers and citizens.

In general, the participation policy in Egypt can be considered a top-to-bottom approach: the government introduced and defined a role through which citizens may participate in the decision-making process. The government therefore has the responsibility to educate citizens about their right to participate. This may be by means of special programs appropriate to local conditions (social, economic, education) designed to inform citizens of their rights and make them aware of the positive results which they can achieve through participation. This will facilitate the transition from a 'top-down' to a 'bottom-up' approach to decision making.

\section{CONCLUSION}

As a newly implemented project the effectiveness of the PSPEV (preparing strategic plans of Egyptian Villages) initiative needs to be assessed. The participation processes that have been examined in this study show that there is a shift away from centralized decision making in favor of policies that promote public participation in Egypt. While these policies initially appear to be appropriate, there have been many complications to implementing them. In addition, there are shortcomings in the implementation of the project, which mean that, while it looks like a fine process on paper, it is not as effective as it seems. As a result, these policies cannot be considered to be truly 'participatory'. According to Arnstein's ladder of participation, the current policy would be classed as being based on consultation, rather than participation. This is due to the fact that the citizens do not have any legislative power or any ability to monitor and enforce the implementation of decisions that have been mutually agreed upon. Additionally, it is clear from the results of the surveys conducted in this study that historical and current political factors continue to negatively affect the quality of public participation in urban planning. This study concludes that there are general procedures that should be adopted to achieve more effective public participation. These include redistributing power to give citizens a means of holding the government responsible for the implementation of strategies agreed to in consultation with the community, and making adaptations to the community consultation process to include more people from special needs groups (such as women, young people, and the disabled) in community consultations, and finally, to stimulate the community's interest in participating.

There is no doubt that policy-making procedures are undergoing a positive shift, and, as with any new system, it isn't surprising that there are problems to overcome before it is perfected. Once the process is refined, however, community-based strategic urban planning has the potential to address many of the urban development problems facing Egypt. Finally, To achieve the objectives of GOPP, improving the participation process alone will not be enough to improve the current urban situation, but it should work seriously in conducting the comprehensive urban policies to deal with the negative aspects in the Egyptian village to achieve the desired goals. 
[1] Sherry Arnstein, writing in 1969 about citizen involvement in planning processes, Her landmark analysis, published as a "Ladder of Citizen Participation", has been reprinted more that 80 times and has been translated into several foreign languages.

[2] General Plans (in the law 3, 1982) identifies the different land uses which include residential, commercial, industrial, tourist, recreational areas and other uses which are consistent with the city nature or the village circumstances, and the needs of the residents.

[3] Local Government Unit (LGU): each unit would have a dual system consisting of Local Executive Council -whose officials are appointed- and Local Popular Council (LPC) -whose members are elected by citizens

[4] Professor: Magdy Radwan, Professor, the head of department of architecture, Asyut University, Personal interview, 15 Feb. 2010, Egypt,

[5] Professor: Khaled El-lethy, Ass, Prof., The main planner of Deer Elbarsha local unit, Minya Governorate, Personal interviews, 10,17 and 20 Feb. 2010 , Egypt.

\section{References}

1) Mostafa Madboly: Sustainable Development of the Egyptian Countryside through Strategic Planning of the Egyptian Villages, the proceeding of the Arab Regional Conference: The interdependence between the rural and the urban, The General Organization of Physical Planning GOPP, Cairo, Egypt, 2005.

2) Abo-Zeed Rageh: the Egyptian Urban: Monitor the Development of Egyptian Urban in the late of Twentieth Century and Survey its future tracks until 2020, the proceeding of the Arab Regional Conference, The interdependence between the rural and the urban, The General Organization of Urban Planning GOPP, the Academic library, Cairo, Egypt, 2007.

3) United Nations Development Program and the Institute of National Planning: Egypt Human Development Report: Egypt's Social Contract: The Role of Civil Society, Commercial Press-Kalyoub, Egypt, 2008.

4) Hatem Mahmoud and Takafumi Arima: The Public Participation Policy as a New Approach to Solve the Urban Problems in Egypt -A Case Study on Asyut city-, Journal of Habitat Engineering, Volume 2, Number 2, pp. 75-86, 2010.

5) Esaam M. Ali and Ahmed H. Salem: Municiapality in Egypt and its role to activate the public participation: The symposium of planning and development of domestic sources of funding, Arab Institute for Urban Development, Khartoom, Sudan, 2001.

6) The General Organization for Urban Planning: The Urban Planning Law no. 3/1982”, Egypt, 2006.

7) World Bank (WB): Analysis of Housing Supply Mechanism, Final Note, Arab Republic of Egypt, Sustainable Development Department, Middle East and North Africa, report no. $41180,2007$.

8) Egypt Law: TheUnified Construction Law (No. 19, 2008), Egypt, 2008.

9) Esam M. Ali: Egyptian village, between reality and the future "Case study villages in Assiut Estate", Journal of the university of king Saud, Vol. 19, Architecture and Planning, pp. 93-132, Saudi Arabia, 2006.

10) The General Organization for Urban Planning: Preparing the Strategic Plans of Egyptian Village - The references book, a governmental document, Egypt, 2005.

11) The General Organization for Urban Planning: The report of Deer Elbarsh Local Unit Strategic Plan - Elbarsha Village”, a governmental document, Egypt, 2008.

12) Arnstein, S: A Ladder of Citizen Participation, AIP Journal, Vol. 35, No. 4, pp. 216 - 224, 1969.

13) Tyler, Nick: Practical Experience of Public Participation: Evidence from Methodological Experiments, , Innovation: The European Journal of Social Science Research, Vol. 16, No. 3, pp. 253-270, 2003.

14) United Nations Development Program and the Institute of National Planning: Egypt Human Development Report: Local Participatory Development, Egypt, 2003.

15) Central Agency for Public Mobilization and Statistics: Egypt in Figures, http://www.msrintranet.capmas.gov.eg/pls/fdl/ab2? lang=1\&lname=, 2010, (accesed 15 Apr. 2010).

16)United Nations Development Program and the Institute of National Planning: Egypt Human Development Report: Choosing our Future "Towards a New Social Contract", Virgin Graphic, Egypt, 2005.

\section{和文要約}

エジプトのナイル沿岸では急速な人口増加に伴って、様々な問題が

顕著化している。特にインフォーマルセクターを形成しながら拡

大する集落の環境改善は急務な課題である。そこでエジプト政府は

2005 年から 4623 集落の戦略計画の意思決定プロセスにおいて、住民

参加の手法を導入している。本論文では、(1)この新たな計画手法導

入の経緯とその具体的内容を整理し、(2)各集落の計画策定に参画し

た大学教員 50 人へのインタビューを通して意思決定プロセスの評価
を明らかにし、(3)さらにワークショップに参加したステークホルダー へのアンケート結果を基にして意思決定方法の評価を明らかとした。 結果として、住民参加プロセスそのものは新たな試みとして評価で きるものの、エジプト固有の問題 : 男性のみによる意思決定、識字 率の低さによる意思決定の難しさ、政府への不信感を背景とした参 加の少なさ、未だ事業化されない計画等の問題を明らかにし、改善 方策を提案した。

(2010年 9 月 8 日原稿受理, 2011年 1 月 6 日採用決定) 